\title{
Missed thyroid gland after total thyroidectomy
}

\author{
Sangar M.Faroq Abdulrahman, Serkan Teksöz, Sina Ferahman, Süleyman Demiryas, Yusuf Bükey, Ateș Özyiğin
}

$\begin{array}{ll}\text { ABSTRACT } & \text { Missed gland is an extremely rare condition. It is a mediastinal thyroid mass found after total thyroidectomy. We } \\ \text { report a case of missed gland. The patient underwent total thyroidectomy due to multinodular goiter and thyroid } \\ \text { stimulating hormone levels did not increase after surgery. Pathological tests revealed a micropapillary carcinoma. } \\ \text { Thyroid ultrasonography and scintigraphy scan revealed mediastinal thyroid mass. The patient underwent redo } \\ \text { surgery without sternotomy and there was no morbidity after the second surgical procedure. Most missed thyroid } \\ \text { gland cases are due to incomplete removal of plunging thyroid goiter during total thyroidectomy. They also can be } \\ \text { attributed to a concomitant, unrecognized mediastinal goiter, which is not connected to the thyroid gland with ves- } \\ \text { sels or a thin fibrous band. It should be noted that absence of signs like mediastinal mass or tracheal deviation in } \\ \text { preoperative chest X-ray does not exclude substernal goiter. The presence of a missed thyroid gland should be kept } \\ \text { in mind when postoperative thyroid stimulating hormone levels remain unchanged. } \\ \text { Keywords: Missed thyroid gland, retrosternal goiter, substernal goiter, total thyroidectomy }\end{array}$

Cite this paper as: Abdulrahman SM, Teksöz S, Ferahman S, Demiryas $S$ Bükey Y, Özyiğin A. Missed thyroid gland after total thyroidectomy. Turk J Surg 2018; 34: 137-139.

Department of General Surgery, İstanbul University Cerrahpaşa School of Medicine, İstanbul, Turkey

\section{Corresponding Author}

Serkan Teksöz

e-mail:serkanteksoz@gmail.com

Received: 17.05.2015

Accepted: 29.07.2015

Available Online Date: 03.01.2018

(C) Copyright 2018

by Turkish Surgical Association

Available online at

www.turkjsurg.com

\section{INTRODUCTION}

"Missed gland" is the substernal portion of thyroid that can be defined as thyroid formation with cervical departure that goes beyond the superior thoracic strait for at least $3 \mathrm{~cm}$ and is connected to the cervical portion of thyroid with or without a thin fibrous band or vascular structure, which is forgotten after total thyroidectomy $(1,2)$.

Missed thyroid gland should be differentiated from autonomous intrathoracic goiter (AIG), which is a thyroid gland formation located in the thorax or the mediastinum, has no parenchymatous or vascular connections with the cervical thyroid gland, and is fed by thoracic vessels. AIG is caused by abnormal embryonic development of the thyroid gland and must be distinguished from migratory goiters or missed thyroid gland after surgery. Here, we report a patient who previously underwent total thyroidectomy with "missed thyroid gland" in the mediastinum.

\section{CASE PRESENTATION}

The patient was a 58-year-old female, who underwent total thyroidectomy for multinodular goiter at our hospital (Figure 1). Thyroid function tests and TSH levels were normal before the first surgery. The thyroid ultrasonography (USG) showed multiple nodules in both lobes, and chest X-ray was insignificant. Thyroid scintigraphy scan was omitted due to normal thyroid function tests. Pathological tests revealed a $0.4-\mathrm{cm}$ micropapillary carcinoma without a thyroid capsule involvement. Radioactive iodine (RAI) treatment was not required. Following the surgery, TSH levels did not increase $(4.7 \mathrm{mIU} / \mathrm{L})$ without levothyroxine replacement. Postoperative USG showed $25 \times 24 \times 24 \mathrm{~mm}$ hypoechoic thyroid gland inferior to the left thyroid lobe with a 10-mm hypoechoic nodule, which was confirmed with a thyroid scintigraphy scan (Figure 2) as a low activity nodular lesion. Fine-needle aspiration (FNA) biopsy revealed a follicular lesion. Surgery was planned and the missed gland was removed without sternotomy through a cervicotomy (Figure 3,4). The patient was discharged one day after the surgery with no postoperative morbidity. A written informed consent obtained from the patient.

\section{DISCUSSION}

If total thyroidectomy is to be conducted, it is of vital importance conduct the operation efficiently and safely. Total thyroidectomy is described as resection of whole thyroid tissue to avoid recurrence (3). "Missed thyroid gland" is an extremely rare condition, which is defined as the appearance of a mediastinal thyroid mass after total thyroidectomy $(1,4,5)$. In majority of the cases, missed gland is a result of incomplete removal of a plunging goiter, although sometimes it may be attributed to a concomitant, 


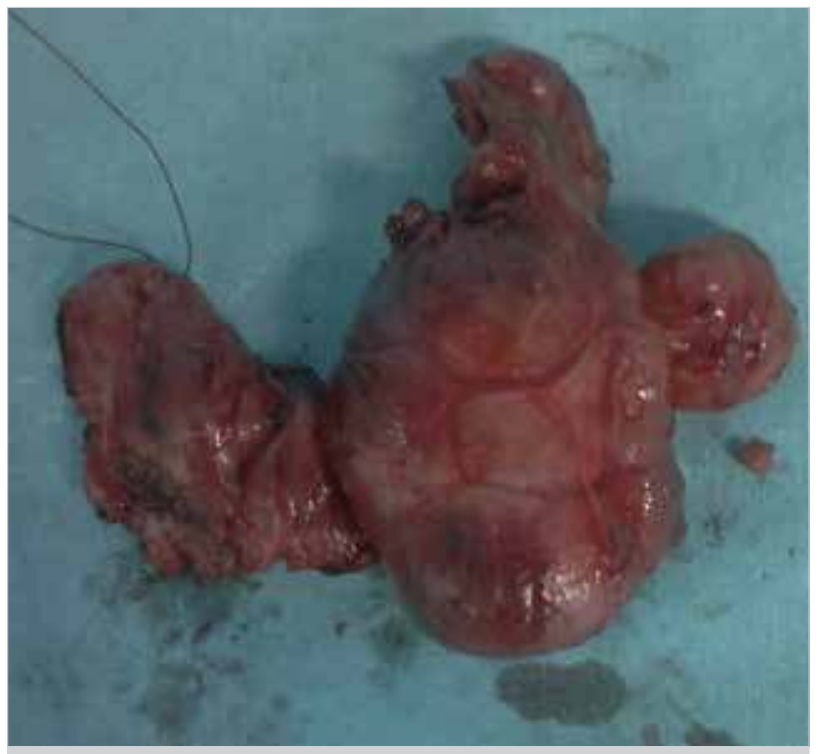

Figure 1. Total thyroidectomy (20.12.2012)

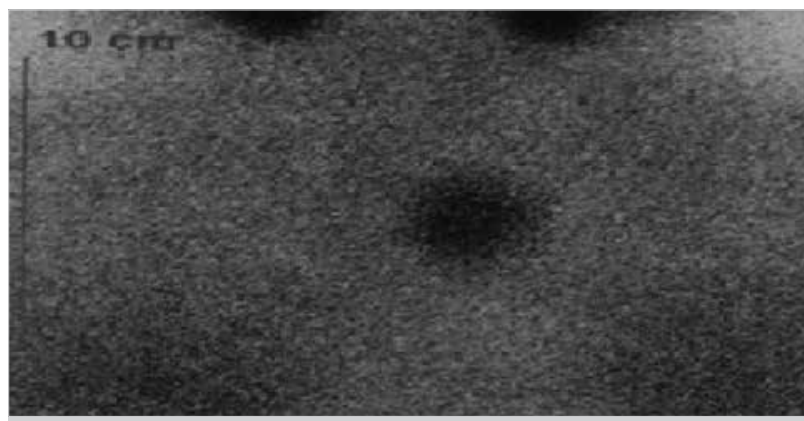

Figure 2. Postoperative scintigraphy: Arrow shows postoperative missed gland (05.08.2014)

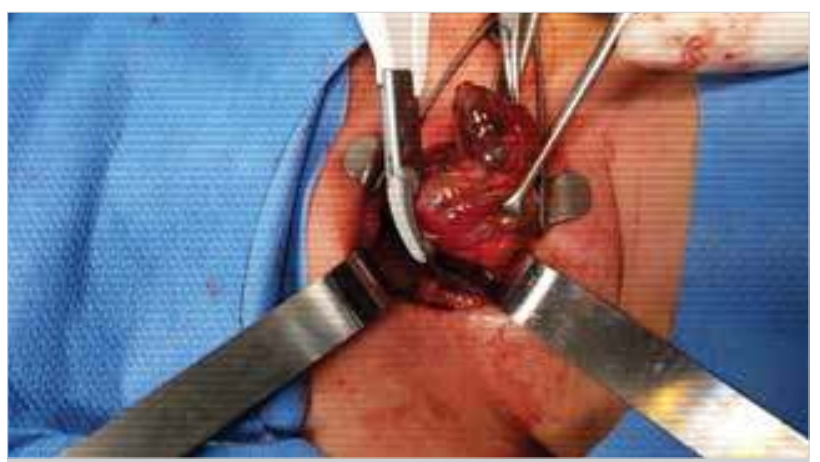

Figure 3. Removal of missed gland (24.11.2014)

unrecognized mediastinal goiter, which is not connected to the thyroid (4). The most frequent recurrence areas that are associated with embryologic location after total thyroidectomy also stand out as anatomical problems. These are pyramidal lobe and thyrothymic and zuckerkandl remnants (3).

There was a rest tissue present in our case at the thyrothymic location. Our case matches $4^{\text {th }}$ grade according to Sacket et al. (6) classification. Also, according to Sacket et al. (6) classification, rest tissues can be missed during total thyroidectomy due to the permanence between thyroid tissue and the $3^{\text {rd }}$ and $4^{\text {th }}$ grade remnants, which constitute $20 \%$ of the remnants. It

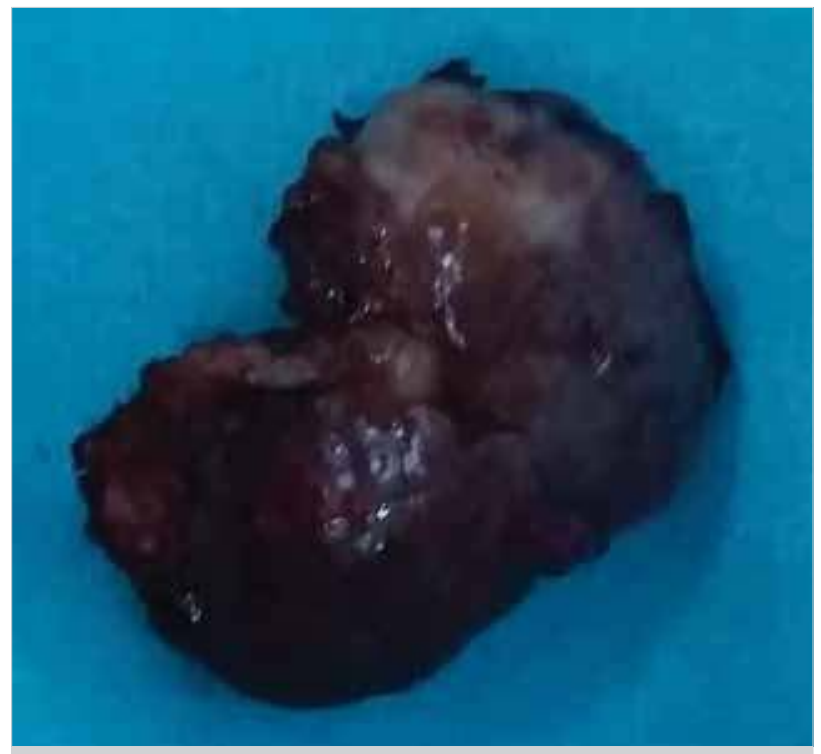

Figure 4. The specimen of missed gland (24.11.2014)

tive imaging and intraoperative management during the first operation $(2,7)$. Thus, routine dissection of pretracheal area and seeing thymus in the thoracic inlet should be a part of every total thyroidectomy that is performed due to nodular goiter. The remnants that underwent nodular change can be frequently palpated during surgery. Retrosternal recurrence can be triggered this kind of thyroid tissue is not dissected completely and this situation may cause patients to face an increased risk of a potential sternotomy need later (3).

A substernal goiter has been defined as an enlarged gland with extension down to the aortic arch with its lower border reaching the transverse process of the 4th thoracic vertebra or below, or with greater than $50 \%$ of the goiter volume present behind the sternum (2). Its incidence varies between $1.7 \%$ and $30 \%$ of all goiters (8). A retrosternal goiter (RG) is commonly defined as having most of its mass in the mediastinum. RG incidence rates range between $2 \%$ and $50 \%$ of all goiters, depending on the definition $(9,10)$. Majority of the patients are asymptomatic, with their goiters detected incidentally during radiologic examinations. Routine chest radiographs seldom miss a mediastinal mass. RG should be suspected if the lower poles cannot be palpated on physical examination (9-11). In our case, there was no symptom due to the remaining thyroid mass in the mediastinum. We did not palpate any mass beneath the thyroid gland extending to the mediastinum during the first operation. As there was no hyperthyroidism prior to the first operation, scintigraphy was omitted. USG and chest X-ray did not show RG and consequently retrosternal area exploration was not performed.

Mediastinal extension is missed during cervical exploration because mediastinal portion of RGs is connected to the cervical part with a thin fibrous band. Absence of mediastinal mass or tracheal deviation in preoperative chest X-ray results in retrosternal area exploration in such cases being omitted $(1,2)$.

Missed gland is a rare pathology; when postoperative TSH levels remain unchanged missed gland should be suspected; however, surgical treatment for missed gland is associated with low morbidity when performed at specialized centers. 


\section{CONCLUSION}

The presence of a missed thyroid gland should be kept in mind when postoperative TSH levels remain unchanged after a total thyroidectomy.

Informed Consent: Written informed consent was obtained from patient who participated in this study.

Peer-review: Externally peer-reviewed.

Author Contributions: Concept - S.M.A.; Design -S.F.; Supervision - S.T.; Resource - S.M.A.; Materials - S.M.A.; Data Collection and/or Processing -S.F.; Analysis and/or Interpretation -S.T.; Literature Search - S.D.; Writing Manuscript - S.M.A.; Critical Reviews - Y.B.

Conflict of Interest: The authors have no conflicts of interest to declare.

Financial Disclosure: The authors declared that this study has received no financial support.

\section{REFERENCES}

1. Batori M, Chatelou E, Straniero A. Surgical treatment of retrosternal goiter. Eur Rev Med Pharmacol Sci 2007; 11: 265-268.

2. Sahbaz A, Aksakal N, Ozcinar B, Onuray F, Caglayan K, Erbil Y. The "forgotten" goiter after total thyroidectomy. Int J Surg Case Rep 2013; 4: 269-271.[CrossRef]
3. Lee J, Delbridge L. Multi Noduler Guatr. In: A. Isgor and M. Uludag, editors. Tiroit. İstanbul, 2013. Nobel Tıp Kitapevi. p.249-262.

4. Riquet $M$, Deneuville $M$, Debesse $B$, Chrétien J. Autonomous intrathoracic goiter. Apropos of 2 new cases. Rev Pneumol Clin 1985; 42: 267-273.

5. Casadei R, Perenze B, Calculli L, Minni F, Conti A, Marrano D. Forgotten "goiter: clinical case and review of the literature. Chir Ital 2001; 54: 855-860.

6. Sackett WR, Reeve TS, Barraclough B, Delbridge L. Thyrothymic thyroid rests: incidence and relationship to the thyroid gland. J Am Coll Surg 2002; 195: 635-640. [CrossRef]

7. Calò PG, Tatti A, Medas F, Petruzzo P, Pisano G, Nicolosi A. Forgotten goiter. Ann Ital Chir 2012; 83: 487-490.

8. Batori M, Chatelou E, Straniero A, Mariotta G, Palombi L, Pastore $P$, et al. Substernal goiters. Eur Rev Med Pharmacol Sci 2005; 9: 355-359.

9. Ríos A, Rodríguez JM, Balsalobre MD, Tebar FJ, Parrilla P. The value of various definitions of intrathoracic goiter for predicting intraoperative and postoperative complications. Surgery 2010; 147: 233-238. [CrossRef]

10. Brian Hung-Hin Lang, Chung-Yau Lo, Gregory W. Randolph. Surgical Management of substernal goiter. In: David J.Terris, Christine G. Gourin, editors. Thyroid and Parathyroid Diseases. 1st ed. New York: 2009. p.90-103.

11. Rodriguez JM, Hernandez Q, Pi-ero A, Ortiz S, Soria T, Ramirez $\mathrm{P}$, et al. Substernal goiter: clinical experience of 72 cases. Ann Otol Rhinol Laryngol 1999; 108: 501-504. [CrossRef] 